https://helda.helsinki.fi

pÿ8=8G5A:89 45=487<8<068=8AB0 0@85=3>D0

\title{
Huttunen, Tomi
}

2014

pÿHuttunen , T 2014 , ' 8=8G5A:89 45=487< 8<068=8AB0 0@85=3>D0 ' , Russian Literature , vol. 76 , no. 1-2 , pp. 167-175 . https://doi.org/10.1016/j.ruslit.2014.11.003

http://hdl.handle.net/10138/153057

https://doi.org/10.1016/j.ruslit.2014.11.003

acceptedVersion

Downloaded from Helda, University of Helsinki institutional repository.

This is an electronic reprint of the original article.

This reprint may differ from the original in pagination and typographic detail.

Please cite the original version. 


\title{
КИНИЧЕСКИЙ ДЕНДИЗМ ИМАЖИНИСТА МАРИЕНГОФА (THE CYNICIST DANDYISM OF THE IMAGINIST MARIENGOF)
}

\author{
ТОМИ ХУТТУНЕН \\ (TOMI HUTTUNEN)
}

\begin{abstract}
The article discusses Imaginist poet, playwright and prose writer Anatolii Mariengof's oeuvre and biography from the point of view of dandyism. Mariengof's literary-historical pose as a dandy is closely related with certain quotes and observations regarding his outlook and garderobe (top-hat, for example). However, cynicist dandyism is also one of the leitmotifs of his poetry and prose, including such thematic elements as "foreigner", "prophet not in his own land", "revolutionary pagliaccio", etc.
\end{abstract}

Keywords: Libertinage; Dandyism; Imaginism; Cynicism; A. Mariengof

Дендизм поэта-имажиниста Анатолия Борисовича Мариенгофа (18971962) сопровождается в истории русской авангардной литературы некоторыми конкретными цитатами-высказываниями, ставшими своего рода самоопределениями для поэта-имажиниста. По всей видимости, сам Мариенгоф очень интересовался восприятием своего внешнего облика, и поэтому охотно вспоминает некоторые отклики с этим связанные. Наиболее известная реплика в этом смысле принадлежит режиссеру В. Э. Мейерхольду, который назвал Мариенгофа “единственным денди республики”. Согласно Мариенгофу, эту характеристику Мейерхольд дал в качестве надписи к фотокарточке, подаренной ему. Представив данную надпись в своих воспоминаниях, Мариенгоф добавил, 
констатируя состояние своего собственного гардероба: “у этого денди было четыре носовых платка и две рубашки. Правда, обе из французского шелка" (Мариенгоф 1990: 121). Кажется, ориентируясь или на Мейерхольда, или на мариенгофское воспоминание, актер В. И. Качалов назвал своего друга "всероссийским денди" и употреблял слово “денди" неоднократно в связи с Мариенгофом. Об этих высказываниях мы тоже знаем только по воспоминаниям Мариенгофа.

Слово “денди” или его синонимы регулярно появляются в связи с Мариенгофом в воспоминаниях других имажинистов и писателей-современников. Достаточно упомянуть слова Ю. Олеши из его воспоминаний:

Некоторые смотрят, как из тумана, другие еще хуже: как бы вошли в тесто. Таким украшением на корке пирога смотрел на меня вчера в ресторане Анатолий Мариенгоф. Боже мой, красавец и щеголь Мариенгоф? (Олеша 1974: 447)

Занятие дендизмом было в глазах современников самодостаточным искусством Мариенгофа, о чем свидетельствует следующее наблюдение поэта-экспрессиониста Л. Болотина:

Да, имажинисты, Есенин и Кусиков, сидя в Германии, льют слезы по России, но возвращаться в нее как будто не собираются. Шершеневич занят в Опытно-Героическом театре, где пишет пьесы $[\ldots]$ ставит и даже играет. А Мариенгоф надел цилиндр, напудрился посильнее, пошел на Тверскую улицу и вполне доволен собой. (Болотин 2005: 322)

Подобные наблюдения, с частым упоминанием или цилиндра, или деллосовского пальто, встречаются в воспоминаниях коллег-имажинистов Рюрика Ивнева, Матвея Ройзмана, Ивана Грузинова, Вадима Шершеневича. Примечательно, что в своих собственных воспоминаниях Мариенгоф ни разу слово “денди” не употребляет прямой речью, а исключительно приводит его в чужих цитатах касательно самого себя. Как известно, это тоже свойственно в сфере дендизма, так как денди - не самозванец, а нуждается в реакции своей аудитории. Имажинисты, как известно, стремились к эпатажу в своем анархистическом городском театре послереволюционных лет. 


\section{Цилиндры}

В городском быту имажинистов Мариенгофа и Есенина важную роль играли цилиндры, которые упоминаются во многих воспоминаниях этого круга. Цилиндры появились на головах имажинистов как будто случайно осенью 1921 года, во время поездки поэтов в Петроград. Примечательно, что этот, очевидно “программный”, сюжет имеет место после того, как Есенин познакомил Мариенгофа с Блоком - кумиром обоих поэтов, названным Мариенгофом “идолом” их поколения. После того, как имажинисты надели цилиндры:

[...] через пять минут на Невском призрачные петербуржане вылупляли на нас глаза, “ирисники” гоготали вслед, а пораженный милиционер потребовал документы. Вот правдивая история появления на свет легендарных и единственных в революции цилиндров, прославленных молвой и воспетых поэтами.

(Мариенгоф 1998: 37)

“Легендарный цилиндр" играет решающую роль тоже в гоголевском и, по всей вероятности, основанном на городской легенде фиктивном эпизоде из воспоминаний Мариенгофа - попытке грабителей украсть у Мариенгофа пальто. Цилиндр и дорогое пальто стали причиной нападения:

Собираюсь свернуть в Косицкий переулок. Вдруг с противоположной стороны слышу:

- Иностранец, стой!

Смутил простаков цилиндр и деллосовское широкое пальто. $(38-39)$

Узнав, что их жертва - Мариенгоф, автор революционной поэмы 'Магдалина' (1920), ночные знакомцы не тронули ни пальто, ни цилиндра, а долго извинялись и проводили его до дому. Важно, что Мариенгофа принимают за иностранца - мотив, который встречается и в воспоминаниях его жены А. Никритиной:

[...] даже мои знакомые рядом с Мариенгофом в цилиндре меня уже не узнавали и мне же рассказывали, какой интересный иностранец появился в Москве, хотя я сама видела, как они пялили на него глаза, не замечая меня. (Никритина 1975: 382)

Цилиндры - не случайные символы имажинистского быта. Существенно, что имажинистов принимают не за тех, кто они есть - в кого бы они ни играли. Критики называли Есенина символистом и Мариенгофа фу- 
туристом. Для Есенина цилиндр стал символом ухода от образа крестьянского поэта и воплощением его собственной лирической темы (см. Эйхенбаум 1995: 120), а для Мариенгофа достаточно естественной реализацией образа современного городского поэта-паяца. Его цилиндр встречается и в стихах Сусанны Мар из сборника $A Б E M$, посвященного Мариенгофу: "И за то, что цилиндр высокий / И прильнул пробор к волосам / Клонит купол Собор Исаакия, / Словно шапку к твоим ногам" (Map 1922: 5).

\title{
Иностранеи
}

Как известно, в словосочетании “имажинист Мариенгоф” мало русского. Оно чужое. Остзейская фамилия (дед Мариенгофа по отцовской линии из Курляндии) сочетается с усвоенным у англо-американских вортицистов названием группы. О вортицистах имажинисты узнали из статьи Зинаиды Венгеровой 'Английские футуристы' (Венгерова 1915: 93-104). Как констатировал Есенин (1995-2002, 6: 126), это интервью Эзры Паунда в сборнике Стрелец было им хорошо известно. Иностранность, инородность фамилии Мариенгофа играется не только в его собственных жизнетворческих текстах, но и в известном стихотворении Хлебникова:

\author{
Москвы колымага, \\ В ней два имаго. \\ Голгофа \\ Мариенгофа. \\ Город \\ Распорот. \\ Воскресение \\ Есенина. \\ Господи, отелись \\ В шубе из лис!
}

В стихотворении фамилия Мариенгофа рифмуется с Голгофой, т. е. она воспринимается как нечто чужое, одновременно как слово Воскресение ассоциируется с “более чем” русской фамилией Сергея Есенина (Левинтон 2000: 71).

Культ инородности, инаковости, иностранности и непринадлежности доминирует в дендизме Мариенгофа. К сомнительной славе садомазохистской "мясорубки" он стремился осознанно своими богоборческими стихами (“Кровью плюем зазорно / Богу в юродивый взор / Вот на красном черным / - Массовый террор...”), находя в этой роли удобную для себя временную “позу”. Коллега имажинист Рюрик Ивнев 
разоблачил очередную чужую маску имажиниста Мариенгофа. Согласно Ивневу, “мясорубка" была лишь удобная маска тихого лирика. И эта, действительно временная, поза становится образом Мариенгофапоэта в истории русской литературы. Во второй половине 1920-х годов эта поза была уже известна критикам. В рецензии на сборник Новый Мариенгоф Л. Повицкий (1926: 242) характеризовал Мариенгофа “тишайшим политическим лириком".

Если садомазохистский революционный энтузиазм Мариенгофа отчетливо выражается в его имажинистских стихах и поэмах, где применяются и обсуждаемые им в теоретических манифестах имажинистские принципы поэзии, то конец этого энтузиазма подчеркивается в поэмах и стихах 1922-1924-х годов, когда завершаются и революционная эпоха, и деятельность имажинистов. Признаки разочарования обнаруживаются уже раньше, в стихах и поэмах 1920-1921-х годов. Наиболее ярко фрустрация, вызванная концом революции видна в его 'Поэме без шляпы', где отчаяние лирического героя сопоставляется с концом имажинистской славы. Там, "С поэм снимая / Траурные шляпы” перед трупом Октябрьской революции, Мариенгоф показывает свое новое отношение к миру. Симптоматично название поэмы 'Разочарование' (1922), где лирический герой обеспокоен ушедшей славой и старостью. Стихи того же года воспроизводят ту же атмосферу. Стихи Мариенгофа 1922 года повторяют разочарование, вызванное концом революции, концом славы, концом активной имажинистской деятельности. Любопытным в этом смысле может оказываться стихотворение 'В моей стране' (1922), которое было найдено в архиве Г. Санникова. В этом тексте воспроизводятся мариенгофские мотивы 1922 года, которые можно встретить также в 'Поэме без шляпы' :

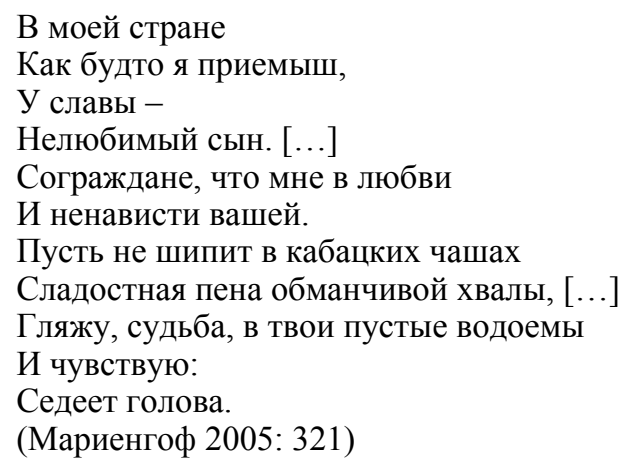

В стихотворении, кроме мотива стареющего денди, возникает мотив “иностранца в своей стране": “О други, нам земля отказывает в материнстве. / Пусть будем мы в своей стране чужими” (ПИ 1999: 261). В 
1924 году уже бывший имажинист Есенин писал свое знаменитое стихотворение 'Русь советская' с посвящением А. Захарову. Нам представляется вполне оправданным считать этот текст репликой, обращенной к Мариенгофу, который пишет в 1922 году: "В моей стране / Как будто я приемыш", Есенин же отвечает в 1924: “В своей стране я словно иностранец". Есенинский текст следует, однако, рассматривать шире - в контексте мариенгофских стихов о разочаровании 1922 года. В другом стихотворении того же года Мариенгоф пишет: "Не нашим именем волнуются народы / Не наши песни улица поет" (ПИ 1999: 262), a Есенин отвечает: “Другие юноши поют другие песни”. Простое сравнение (Есенин: “словно”, Мариенгоф: “как будто”) несет особый имажинистский оттенок. Согласно околоимажинистскому деятелю, экспрессионисту-скандалисту Ипполиту Соколову (2000: 268), краткое сравнение с соединительным союзом обеспечивает динамическую структуру имажинистского образа.

Тексты Есенина и Мариенгофа говорят о том, как лирические герои оказываются “чужими”, не “своими” в Советской России времени конца революции, начала нэпа. Мариенгофский герой, который в поэме 'Магдалина' (1920) был революционный “недоносок” или “выкидыш”, оказывается теперь “приемышем", чужим и нелюбимым страной и читающей публикой. Есенинский герой, вернувшийся "в край осиротелый”, ощущает отчужденность родного языка и чувствует себя лишним. Этот имажинистский диалог тем более интересен, что стихотворение Есенина было воспринято, как его явный стилевой уход от “бурного имажинизма" к спокойному классическому стиху.

\section{Кинический пророк}

Позиция чужого пророка в своей стране или иностранца существенна для Мариенгофа и имажинистов, которые стремились к тому, чтобы не быть похожими на представителей нового общества и отталкивались от всех господствующих веяний моды послереволюционной эпохи. Также вполне обоснованно предположить, что Мариенгоф назвал свой роман 1928-го года Циники, сопоставляя имажинистов с греческой школой философии т. н. киников. Некоторые сходства между “школами” любопытны. Мы имеем в виду неприятие киниками государства, которое противопоставлялось личности как "враждебная внеположенная сила". Кажется, определяемое часто как "аморализм" или "цинизм" мировоззрение имажинистов сопоставимо с философией киников, так как его следует характеризовать скорее имморалистским, чем аморалистским. Хотя эпатажное самолюбование и дендистский нарциссизм имажинистов противоречат идеалам греческих киников, аналогию можно усмо- 
треть именно в их идее индивидуализма. Он носил не только эстетический, но и политический характер. Индивидуализм и анархистский отказ от господствующих ценностей доведены до критического предела в статье Вадима Шершеневича 'Искусство и государство' (1919). Имажинисты рады тому, что государство их не признает:

Искусство не может свободно развиваться в рамках государства
$[\ldots]$ как только искусство будет отделено от государства, одно из
течений возьмет в свои руки власть и будет диктатором [...]. Мы -
имажинисты - группа анархистического искусства - с самого
начала не заигрывали со слоновьей нежностью с термином, что мы
пролетарское творчество, не становились на задние лапки перед
государством. Государство нас не признает, и слава Богу! Мы
открыто кидаем свой лозунг: Долой государство! Да здравствует
отделение государства от искусства! [...] Да здравствует дик-
татура имажсинзма! Под наши знамена - анархического има-
жинизма - мы зовем всю молодежь, сильную и бодрую.
(Шершеневич 1919: 5)

В декларативной книге $2 x 2=5$ (1920) Шершеневич писал, что имажинизм представляет собой индивидуализм в эпоху коллективизма, тогда как футуризм - несмотря на декларирование индивидуализма - является коллективистским искусством: “в эпоху государственного коммунизма должно родиться в искусстве такое индивидуалистическое течение, как имажинизм" (1920: 5).

Отдельный сюжет, отчасти подтверждающий вышеупомянутое сопоставление (имажинисты - киники), можно видеть в планах Мариенгофа написать в конце 1920 -х годов - до романа Циники - роман под названием Записки бога, т. е. дневник философа Иисуса, который общается в Афинах со своими современниками-философами. В третьей части своей мемуарной т. н. Бессмертной трилогии Мариенгоф рассказывает сюжет недописанного текста, для которого он собирал материал. В несохранившейся истории обращают на себя внимание намеки на гомосексуальные отношения между Иисусом и Иоанном: "Покинул Иисуса даже Иоанн, его юный нежный возлюбленный” (Мариенгоф 1994: 95). Основные действия романа имеют место после того, как “женщины, обожавшие Иисуса, сняли его с креста прежде, чем он умер” (там же). Иисус покинул Галилею, добрался до Афин, в город философов, где он жил среди стоиков, эпикурейцев и киников. Услышав, как апостол Павел рассказывает народу фантастические и наивные истории о его жизни и совершенных им невероятных чудесах, Иисус решил написать Записки Бога, своего рода мемуары. Это должна была быть история пророка на чужой земле, но Мариенгоф своего плана не осуществил. Он выступает с позиции исторической критики, и свиде- 
тельство такого восприятия библейских текстов можно обнаружить во всем его творчестве. Отголоски этого неосуществленного "прототекста" в романе Циники можно увидеть в революционности образа Христа, хотя эпатажный текст в принципе характерен для Мариенгофа. Вместо осуществления этого плана Мариенгоф взял и писал Циников, свою первую работу в художественной прозе, полную прототипических мотивов, аллюзий и прямых отсылок к истории имажинизма конца 1910-х начала 1920-х годов. И этот текст оказался его главным достоянием в истории русской литературы.

Хотя мариенгофский имажинистский “запоздалый”, несвоевременный дендизм несет фрагментарные оттенки "истинного" дендизма, например, Браммеля, он далеко не полностью сопоставим с восприятием, например, Оскара Уайльда в русской культуре начала XX века. В имажинистской группе Мариенгофу приписывается маска двуликого эстета, денди-арлекина. Центральное для самоопределения имажиниста Мариенгофа противопоставление тихого лирика и пламенного паяца встречалось наиболее ярко в его поэме 'Магдалина' (1920). На самом-то деле, как показывают многие высказывания современников и представителей круга Мариенгофа, именно тихий лирик - его настоящий поэтический облик, а пламенный паяц лишь маска. Анархистский индивидуалистский имажинизм сталкивается с утонченным щегольством, а революционный эпатаж поэта-паяца с тихой лирикой разочарованного поэта. В этом коктейле, как нам кажется, состоит кинический дендизм поэта Мариенгофа. Наиболее адекватное описание этого самоопределения можно найти в автобиографической трактовке его первого художественного романа Циники.

ЛИТЕРАТУРА

Болотин, Л.

2005 'Литературная Москва'. Русский экспрессионизм. Теория. Практика. Критика. Москва.

Венгерова, 3.

1915 'Английские футуристы'. Стрелеи. Сб. первый. Петроград.

Есенин, С.

1995-2002 Полное собрание сочинений. Москва.

Левинтон, Г.

2000 'Рецензия на книгу Барбары Леннквист "Мироздание в слове. Поэтика Велимира Хлебникова”". Новая русская книга, № 4-5 (5-6), 71-75. 
Map, C.

1922

Мариенгоф, А.

1990 'Мой век, моя молодость, мои друзья и подруги'. Мой век, мои друзья и подруги. Воспоминания Мариенгофа, Шершеневича и

1994 Грузинова. Москва.

1998 Это вам, потомки! Санкт-Петербург.

2005 Бессмертная трилогия. Москва.

Никритина, А.

1975 'Есенин и Мариенгоф'. Есенин и современность. Москва.

Олеша, Ю.

“В моей стране...”. Вопросы литературы, № 5, 321.

1974 Ни дня без строчки. Москва.

ПИ

1999 Поэты-имажинисты. Санкт-Петербург.

Повицкий, Л.

1926 [б.з.] Красная новь. № 11, 242.

Соколов, И.

2000 'Имажинистика'. Литературные манифесты от символизма до

Хуттунен, Т. наших дней. Москва, 266-275. 2007

Имажинист Мариенгоф: Денди. Монтаж. Циники. Москва.

Шершеневич, В.

1919 'Искусство и государство'. Жизнь и творчество русской молодежи, № 28-29.

$1920 \quad 2 \times 2=5$. Москва.

Эйхенбаум, Б.

1995 'Смерть Есенина'. Revue des Études slaves, LXVII, f. 1. 